\title{
Music Early Learning Programs: Enduring outcomes for children and their families
}

Margaret S Barrett 1,2 and Graham F Welch 3

1Sir Zelman Cowen School of Music, Monash University, Victoria, Australia

2The University of Queensland, Brisbane, QLD, Australia

3Institute of Education, University College London, London, UK

Corresponding author: Margaret S Barrett, Sir Zelman Cowen School of Music, Building 68, 55 Scenic Boulevard, Clayton Campus, VIC 3800, Australia.

Email: margaret.barrett@monash.edu

\section{Abstract}

Music early learning programs (MELPs) that provide music services to parents and carers of children aged birth through 8 years are proliferating. Parents make significant financial and social investments in MELPs, yet little is known of their motivations and aspirations nor of the enduring outcomes of participation. This article reports the findings of an interview study with 10 parents, 1 grandparent, and 8 child former participants in a MELP program in regional Australia that investigated perceptions of MELP participation. Findings indicate that parents come from a range of musical backgrounds. Reasons and aspirations for MELP enrolment encompass developing both parents' and children's musical skills, providing social benefits for parent and child, exposure to musical experience, value-adding to their child's education and expanding the family social circle. Enduring outcomes include developed music knowledge and skills, future investments, physical and emotional development, and new patterns of learning that are potentially transferable. Findings suggest that children arrive at formal schooling with a rich repertoire of music, a capacity to engage in embodied musical experience, and a set of expectations concerning their participation in music. Such knowledge holds implications for the ways in which music learning might be structured within the early childhood classroom.

\section{Keywords}

music early learning programs (MELPs), early childhood, learning, lifespan, wellbeing, singing, infancy, parents 


\section{Introduction}

Infancy and early childhood (EC) are periods of rapid development and growth shaped through the interaction of a child's genetic heritage with their experiences in family and community (Rogoff, 2003). There is an expanding literature on the effects of music on various aspects of learning and development including cognitive, social and emotional development (Barrett et al, 2018; Maróti et al, 2018; Williams et al, 2015), and health and well-being outcomes (Hallam, 2015, 2016; Blackburn, 2018). Much of this literature has focused on school aged children, with less attention given to investigating the role of music in children's early life (birth through infancy). Investigations of the effects of music engagement for young children, including those enrolled in early years programs (aged 3 to 8 years), identify a range of extra-musical benefits, including: increased pro-social behaviour (Kirschner \& Tomasello, 2009, 2010); increased emotional empathy scores (Brown \& Sax, 2013); increased phonological processing and early reading ability (Anvari et al., 2002; Gromko, 2005; Kraus et al, 2014); improved self-regulation (Williams \& Berthelsen, 2019); and increased spatio-temporal awareness (Gromko \& Poorman, 1998). Studies have indicated that young children (aged 18 months to 60 months) use music, primarily as invented song, in their identity work (Barrett, 2011, 2017; Sole 2017), as a means of communication with self and others (Barrett, 2009; Custodero, Cali, \& Diaz-Donoso, 2016; Nome, 2018), as a means to explore and express their understandings of the world (Barrett, 2003, 2006; Gudmundsdottir, 2018; Ilari, 2016), and as a means to self-regulate and self-comfort (Barrett, 2016; Sole, 2017; Winsler et al , 2011).

Studies of music-making in families indicate that shared music-making experiences between carer and child can contribute to positive life and learning outcomes for the child, function as a tool for behaviour and mood modification, and play a role in establishing family traditions (Barrett, 2009; Custodero \& Johnson-Green, 2003). Recognition of the importance of music in early learning and life has contributed to a proliferation of Music Early Learning Programs (MELPs) in a range of formats and settings (Abad \& Barrett 2017). Parents who enrol their children in MELPs make a significant financial and social investment, yet little is known of their motivations and aspirations for enrolling their children in these programs, nor of the enduring outcomes of participation. This article reports the findings of an interview study with 10 parents, 1 grandparent and 8 child former participants in a single MELP program in regional Australia that aimed to investigate their perceptions of participation in MELPs. 


\section{Theoretical Background}

Music Early Learning Programs have been described as the 'new frontier of music education or intervention aimed at infants, parents and even expectant parents' (Adachi \& Trehub, 2012, 229). MELPs have been defined as '...a program that has been designed by a qualified music teacher, community musician, or registered music therapist with the intention of nurturing a love of music, supporting musical and extra-musical development in the child, and empowering the parent to use music in the home' (Abad \& Barrett, 2016, 139). For Adachi and Trehub $(2012,245)$, MELPs have potential to '...feed into contemporary middle-class anxieties about parenting skills and children's future achievement' and are therefore not an unalloyed good. As an indication of the pervasiveness of MELPs, a search conducted in February 2018 for "Music Early Learning Programs in Brisbane" yielded 202,000 results offering classes. MELPs in the region include single business owners offering classes to their local community, to franchise businesses, and international businesses-such as Kindermusik - that register practitioners following compulsory training. The MELP industry is rapidly expanding and draws on the findings of recent advances in science that evidence the importance of music in young children's early learning and development as its evidence base and rationale (Adachi \& Trehub, 2012). Common features of such programmes are instructor-led singing, moving, dancing and percussion experiences, exploring rhythm, melody, tonality and pulse. Research suggests that MELP participation enables participants to share musical moments that support social, emotional and intellectual development (Abad \& Barrett, 2016). Recent studies (e.g., Pitt \& Hargreaves 2017a, 2017b) have investigated parents' and practitioners' perspectives of the rationale for the inclusion of group music activities in children's centres in England. These centres provide generalised education and care where music may be just one aspect of the daily program rather than the primary function of the program, as in a MELP. An initial interview study (Pitt \& Hargreaves, 2017a) identified a distinction between parents' and practitioners' views, with parents emphasising social, emotional and learning benefits for their children from attending group music sessions, whilst practitioners emphasised the learning and development benefits for children. Outcomes of parental attendance at the sessions included increased musical activity, primarily singing, in the home. A subsequent survey study reinforced these findings, but also raised issues concerning the working practices of practitioners who include group music in their programming, specifically in relation to a limited professional training background (Pitts \& Hargreaves, 2017b). 
Other studies of music offerings in early learning and care settings indicate that parent participation not only provides a music learning opportunity for parents on which they subsequently draw in their home parenting practices (Ilari, Moura \& Bourscheidt, 2011; Morris, 2013; Young, Street \& Davies, 2007), but also may function as a means to combat parental isolation for those in socially and economically disadvantaged settings (Scott-Hall, 2005), and contribute positively to the mental well-being of adult carers, including mothers (Fancourt \& Perkins, 2017; Gudmundsdottir \& Gudmundsdottir, 2010; Kawase \& Ogawa 2018).

The MELP industry in Australia and internationally is largely un-regulated, leading to a diversity of practice and quality from program to program. Nevertheless, as the key focus of a MELP is music participation, it might be assumed that the group leaders possess a greater degree of knowledge and skill in leading music sessions than might be evidenced in those employed in the general early learning and care sector, including children's centres and generalised childcare services. It might also be assumed that parents' and carer's motivations for attending a MELP are primarily musical in nature and that they hold a high value for music in their own and their children's lives. In order to interrogate these assumptions, this research explored the following questions:

1. What are the musical backgrounds of parents who enroll their children in a MELP?

2. What are their reasons for enrolling their child in a MELP?

3. What are their aspirations for their child's participation? and

4. What are the life and learning outcomes for their child from participation?

\section{Method}

The investigation constituted one strand-titled retrospective perceptions of the learning and life outcomes of participation in MELPs - of a longitudinal study of musical parenting and young children's music-making in Australian families (Barrett \& Welch, 2013 - 2016). Data were generated through individual and joint interviews with 10 families who had a history of long-term participation in a single MELP located in a city in regional Australia. The focus on retrospective interviews with parents and their children with a long-term history of participation rather than current attendance was intended to provide opportunity to probe any perceived enduring outcomes of participation in these childrens' and families' lives and learning. Additionally, given the age-range of children attending MELPs (birth through to 5 years), interviewing past participants 
provided an opportunity to engage with children to obtain their perspectives on remembered early life experiences with music, rather than relying solely on the reports of their parents and carers.

Following the granting of ethical permission (University of Queensland Human Research Ethics Committee), participants were recruited via a Third Party: the Director of the MELP forwarded information sheets and letters of invitation to families in the target demographic, i.e., past participants in the program with a long-term (one or more years) history of engagement. Nineteen participants (adults, children) were interviewed, some singly, others in a family group (see Table 1). Interviews were conducted primarily face-to-face (8), with two parent interviews conducted via telephone. Individual interviews were conducted with the parent or carer ( 1 grandparent) who had participated in the MELP. Interviews with children were conducted with parents ( 5 interviews, $n=8$ child/adolescent participants). This arrangement was at the parent's request for convenience, as many had travelled long distances from surrounding farms and districts. Children participated freely in the interviews, with interviews becoming a conversation in which participants reminded each other of events, experiences, and enduring outcomes. Interviews probed retrospective perceptions of individual and family drivers for participation, use of MELP experiences in the home, and enduring outcomes. Interviews were recorded and transcribed. Interview transcripts were checked against recordings and analysed using an analysis of narrative approach (Polkinghorne, 1995) to identify emergent themes. Both investigators analysed the interviews separately and consulted to corroborate and confirm the emergent categories. As the aim of the analysis was to understand the phenomenon from a range of perspectives rather than quantify the frequency of particular responses, sections of text were identified to support emergent themes across the full data-set. These were subsequently presented as narrative vignettes in order to provide rich detail of these participants' experiences. Thus, findings identify and differentiate the perspectives of parent, carer, and former child participants. 
Table 1: MELP Past participants (pseudonyms)

\begin{tabular}{|c|c|c|}
\hline Interview participant/s & Program participants & $\begin{array}{l}\text { Child's commencing age in } \\
\text { program }\end{array}$ \\
\hline Sally (mother) & $\begin{array}{l}\text { Sally and } 3 \text { children }\left(\mathrm{F}^{1}{ }^{1} \text {, }\right. \\
\mathrm{M9} \text {, and } \mathrm{F} 6 \text { years) }\end{array}$ & $8-12$ months \\
\hline $\begin{array}{l}\text { Marion (mother) and Amy } \\
\text { (F12 daughter) }\end{array}$ & Marion and Amy (F12 years) & 6 months \\
\hline Stella (mother) & $\begin{array}{l}\text { Stella and } 4 \text { children }(14,12, \\
11,9 \text { years })\end{array}$ & 3 years \\
\hline Brenda (grandmother) & $\begin{array}{l}\text { Brenda and } 4 \text { children (14, } \\
12,10,8 \text { years) }\end{array}$ & 2 years \\
\hline Michaela (mother) & $\begin{array}{l}\text { Michaela and } 3 \text { children } \\
\text { (F19, M17, M11 years) }\end{array}$ & 3 years \\
\hline Ellen (mother) & $\begin{array}{l}\text { Ellen and } 2 \text { children (F14, } \\
\text { F10 }\end{array}$ & 9 months \\
\hline $\begin{array}{l}\text { Lenora (mother), Sylvie and } \\
\text { Hilde (F12 and F8 } \\
\text { daughters) }\end{array}$ & $\begin{array}{l}\text { Lenora and } 2 \text { children (F12, } \\
\text { F8) }\end{array}$ & 3 years \\
\hline $\begin{array}{l}\text { Kara (mother), Max (father) } \\
\text { and Joe (M15 son) }\end{array}$ & Kara, Max, and Joe (M15) & 4 years \\
\hline $\begin{array}{l}\text { Sarah (mother) and Luke } \\
\text { (M14 son) }\end{array}$ & $\begin{array}{l}\text { Sarah and } 5 \text { children (M14, } \\
\text { M12, MM9 - twins) }\end{array}$ & 18 months \\
\hline $\begin{array}{l}\text { Sandy (mother), Carl (M10 } \\
\text { son), Ricky (M7 son) and Lily } \\
\text { (F4 daughter) }\end{array}$ & $\begin{array}{l}\text { Sandy and } 3 \text { children (M10, } \\
\text { M7, F4) }\end{array}$ & 2 years \\
\hline
\end{tabular}

F12: Coding indicates gender $(\mathrm{F}=\mathrm{Female} ; \mathrm{M}=\mathrm{Male})$ and age 


\section{Music Early Learning Program description}

The MELP that is the focus of this investigation is an independent Music Early Learning Program of some 20 years standing, based in a regional city (population approx. 100,000) in Australia. The city services large-scale agricultural and forestry industries. The MELP program draws on the resources of the Kindermusik programs and offers:

- group music and movement classes for children and parents from 3 months to 18 months to age 3;

- group music and movement classes for children and parents from 18 months to age 3;

- group music and movement classes for children from age 3 to age 5;

- group glockenspiel and/or keyboard classes from age 4; and

- individual keyboard instruction from age 5.

Group classes for parent and child include singing and movement, instrumental play, together time, listening to a broad range of musical genres, and story time. Parents may purchase additional resources ( $C D s$, instruments, books) to continue the MELP experience in the home and are encouraged to do so.

\section{Findings}

\section{RQ1: What are the musical backgrounds of parents who enrol their children in a MELP?}

The parent-carer participants displayed a range of music backgrounds from tertiary qualifications in music to no formal music education. In some cases, participants spoke of music-rich family environments, where parents and siblings, both formally trained and self-taught, played together in family celebrations and church and community events. These "hidden musicians" (cf Finnegan, $1989,2007)$ provided models of music learning and music-making, compensating in some instances for a lack of school music education. A number of these elements were evident in participants' continuing family practices. For others, their musical childhood was as 'Just a listener' (Marion).

"Hidden musicians" in informal family music environments

I can remember from a very young age my mum used to sing...she sang all the time...I remember going to weddings and dinner dances when I was about three or four, and my Dad 
(he had no musical training, didn't really know what he was playing, but could play by ear), would pick up a guitar and just start to strum and sing at somebody else's wedding...I have lots of memories of my parents singing. My eldest brother was quite musical and learnt guitar for a few years. We did go to church a little bit... I went to a Catholic school, and when we went to Church we had to do lots of singing as well.... And I remember when I was a kid I loved to tinker on other people's pianos, and one became available and I started playing piano when I was eight... I can remember being really excited about learning piano. It was never anything forced. I really wanted to learn... For the first few years, absolutely loved it. And then I started doing exams and didn't love it quite so much after that... There was always music playing, whether it be a record or a tape in the car, or someone singing in our house. So, there was music around a lot when I was growing up (Sally).

Sally continued piano lessons to grade six AMEB level and now considers herself musically 'on $a$ scale of one to ten, I'm probably halfway along or perhaps even two-thirds'. She describes being musical as 'being fairly easy with it, so not being frightened of music, or not being frightened of singing, or not being frightened of creating a sound for fear of being wrong...'. She goes on to describe the ways in which she uses music in the family:

I sing with my kids. I play guitar and sing. I listen to music...if there's something that we have to remember, like a rhyme or that kind of thing, then we try and put it to song. We had some musical instruments around the house that we just muck around with. We've got a djembe and some bongos and couple of ukeleles. And my husband has a didgereedoo that my son dabbles with.

A number of parents in the study had undertaken formal instrumental lessons. For many the starting age was eight years, with the most common instrument the piano (Sally, Stella, Ellen, Brenda, Lenora, Kara). Whilst some persevered with the piano through a graded examination series (Sally), others embarked on other instruments. As Stella comments 'I decided the piano was too dominant an instrument and too immovable, so I took up the flute (self-taught) so I could play at church, or where-ever I could take it and play'. Stella, the eldest of three children, describes a family approach to music-making which drew on the formal music training of each of her siblings to contribute to community music-making in family and the church. 
'My other sister learnt the flute as well and another sister learnt the clarinet and my Dad used to play the guitar (he never had lessons). So, we sort of had a timeslot at church where we'd play the music. It was us and another family... and we would play the music for that service and we did that about once a month. So, we used to have a bit of a jam session and practise up a few pieces and that sort of thing'.

Stella describes a family environment in which music is drawn upon for special celebrations '...if it was a special birthday, we might even write a song for that person', where her mother's love of classical music provided one soundtrack, whilst her father's love of jazz provided another. Stella speaks of the family taking long road trips (Alice Springs to Melbourne) in which 'the necessary road trip songs' were sung by all. She continues 'Occasionally, if we all get together, we will get out our flutes and play some music, at Christmastime, for example'. This rich formal and informal family music environment provided a counterpoint to an apparent lack of music education in Stella's schooling.

Lenora recalls her 'father's family were very musical. And I remember as a child my grandmother, my grandfather and my father and my aunt all around their piano in Melbourne, my aunt singing, she had a beautiful contralto voice, and my grandmother playing the piano, my grandfather playing his cornet...and my father playing his trumpet...just playing all sorts of duets and musical things'. She describes the travelling life of an army child, moving from base to base across the country, the family always accompanied by 'this beautiful Ronisch piano'. Lenora had two years of lessons in one location 'because that's how long the posting was', sufficient to be able to contribute to the family music-making, accompanying her father. He, in turn, 'would hack out something on the piano because he was more of a trumpeter, (while) my mum and sister and I used to sing lots of musical type Sound of Music sort of songs...'. Throughout her years of schooling which included an overseas posting, Lenora sang in choirs and continued to play the piano with occasional lessons from a friend at university. Primarily, she 'sort of picked it up myself and taught myself and probably got up to about Grade three level'. Church attendance provided a further avenue for family music-making, with Lenora's father and aunt singing duets in services.

Family traditions of singing around the piano were also part of Kara's childhood experience with 'Saturday night, all the cousins, all the rellies singing, someone will play the piano. Family do's in a 
big hall, everyone would be singing. So, they were musical, but my parents didn't learn music, either of them'. With a solid background of classical music lessons, Kara picked up guitar when she started teaching and uses both guitar and piano 'just to sing songs in the classroom with the kids. Like I might be teaching them something or we might be doing a performance for assembly and I'll play'.

One participant, Brenda (a grandparent), recalls a childhood rich in music-making. 'I learnt the piano. My Dad was a singer, just locally. He used to sing in the local musical, and in the church choir...and we used to have musical evenings with grandparents and cousins...(playing) at all the dances, and I was in the choir with my music teacher, the school choir and the choir at church and then I played the organ...'. Following a move to the city, marriage, three children in quick succession, and single parenthood when her oldest child was three and her youngest six months, active music-making disappeared from her life and-due to financial and time pressures as a single parent-was not a possibility for her girls. 'I couldn't afford to give them piano lessons... we used to sing songs before they went to bed...I always still had my records, played my records all the time, so there was lots of music in the house'. Despite these setbacks, Brenda's continuing passion for music and her belief in its vital role in young children's lives is evidenced in her enrolling and taking all four of her grandchildren to the MELP, thus ensuring 'they all have music in their life'.

\section{'Just a listener'}

By contrast to the engaged active music-making evidenced in the accounts above, for Marion, music participation in the family environment was primarily as 'Just a listener'. She continues 'It would be country [music]... a lot of country and the radio, the radio was always playing. It was Slim Dusty..it was Led Zeppelin.. a lot of that heavy stuff, Pink Floyd'. Recollecting music in school, she describes it as '...pretty poor... We did it, I remember in form four, year seven...that was about all we were exposed to at school'. She describes her husband's music education as, 'A bit the same as me, just a listener...'. Despite these poor beginnings, her husband has taken up guitar, learning through '...the internet, through tabs... and he plays great now... First year I had earplugs that I walked around in, yeah'. The motivation for learning guitar was two-fold: a long-held desire to play the instrument, and an emerging desire to play alongside his daughter Amy, who had begun guitar lessons after attending the MELP. 


\section{Nothing...it just wasn't there}

Sandy cannot recollect any music in her childhood years beyond singing along to the radio from the ABC 'Let's Sing' books once a week in Primary school. Her home experience was 'nothing...mum wasn't really into music'. It was not until her stepfather joined the family (age 10) that music, (Country and Western), and music-making (playing the guitar and keyboard) became part of her life. At the age of 16 she took some keyboard lessons, but due to financial circumstances, other opportunities were not possible.

For Sarah, music 'just wasn't there' in her childhood. Her first encounter with music learning occurred in her teacher education course where she had learned to play the guitar 'really, really badly'. She credits her time at university as exposing her to the possibilities and contributions of music in children's learning and development.

Michaela describes her parents as musical, but cannot recall any formal music learning in her childhood. As the daughter of a farmer in a remote rural district, the main exposure to music was at church where 'there was only an organ' and her parents occasionally playing the piano 'by ear'.

It is evident from the diverse experiences outlined above that a high value for music does not necessarily arise from a parents' own music education experiences, nor indeed from the models demonstrated within the family and community setting. Rather, their experience of having children opened up musical possibilities in their own lives. Marion's daughter Amy commented, 'Well, at home, I'm feeling happy and that. We put on a bit of music. We used to have, when I was little, music nights, and we'd all dance around to the music, that was fun' (Amy).

\section{RQ2: What are their reasons for enrolling their child in a MELP?}

Parents' reasons for enrolling their child in the MELP not only pertained to their beliefs in the benefits of participation for their child, but also as a means to develop their own musical knowledge and skills $(n=3)$, to redress an absence in their own childhoods $(n=3)$, andoverwhelmingly - to provide social benefits for themselves as parents $(n=7)$. For one family, attendance at the MELP provides the music component of a home education curriculum (Lenora). 
Develop parents' musical knowledge and skills

In discussing her reasons for attending the MELP Sandy not only remarks on strengthening her own musical knowledge and skills, she also references more generalised learning strategies.

I've learnt I guess an awareness in myself ...not to become daunted by the enormity of something and to look at it bit by bit. The MELP leader taught me about...children and how they develop different things at different times, and I always read her little captions she puts up, and she talks about different stages of brain development and how that's all gone...OK it's normal... and seeing the diversity in the class. Like there's those that are just switched on to everything immediately, and there's those that take time to develop those skills...there's the social side, the cognitive side, there's the auditory processing...I definitely learnt to appreciate that they all develop differently...'.

Redress an absence in parents' childhoods

Sandy's lack of music learning experience in her own childhood was a primary reason for her enrolling her children in the MELP.

'I would have loved to do something when I was younger, and I guess that's part of the reason I wanted to offer it to my children, because it played an emotive part in a lot of the stages of my life...my husband is the same. He didn't start playing his instrument until he was 15 or 16 and he was always saying he wished he'd had lessons from an earlier age...it would have just come more naturally. He wouldn't have had to work quite as hard...So that's why we chose nice and early with them and see whether they take an interest in music...it was more of an invitation to them that if they enjoyed it then we would go on with that'. Sandy describes her own household as rich in music-making with both parents playing, with music in the house 'all the time...I mean we drove (here) all the way singing, didn't we? (Addressed to her son).

Michaela recalls seeing an advertisement for the MELP and saying 'Oh my goodness I want for my child what I never had'.

Provide social benefits to the parent For some parents enrolling in a MELP provided a means to combat isolation. As Marion comments 
'It was probably more for me than for her at that age (6 months)... being an older mother, I didn't do all that mother's club sort of thing and stuff like that. I just thought, well, being exposed to music is a good thing and I took her, and it was an outing for me. I met some friends which we've been friends ever since... There's three of us who did it all the way through with our girls, and we still see each other and have coffee and the girls all go to different schools and everything, but we always try and get together and they've got a good bond there (Marion).

Combating social isolation was not only a benefit for the parent, as Amy her daughter notes 'And I met really good friends that I'm still friends with today'.

Whilst increasing their social circle might not have been the primary motivation for enrolling their child in the MELP, many spoke of the social benefits that had accrued from participation. Sally recalls,

'I think I heard about it [MELP] on the grapevine...And I went and had a go, and I absolutely loved it. And I can remember there was probably only three or four people in the group. And to this day, I'm still really good friends with one of the people in that very first class that I went to, and our girls are really close mates as well'. Stella speaks of the opportunity the MELP provided to 'do something outside of my home, especially with babies and then more babies. So, I enjoyed it socially as well'.

For Ellen, attendance at the MELP played an important part in her recovery from post-partum depression.

'When I had my first baby, I had a lot of problems and I was diagnosed with post-partum and I recognised that I needed to get out of the house and I needed to engage with other people, but it was very difficult for me to do. I got involved with [the] MELP and it was a way that I could get out of the house for my child because that seemed to be - I could do things for her, but I couldn't do it for me which kind of sounds backwards.... Hubby and me decided that we would do MELP because I was still able to be with the girls, but I wouldn't have to talk with anybody else in the room.... It got me out of the house and it became a focus of things that we could do during the day. We have to read this book this week. It would also become a focus. We'd have to put the tape on to the CD. We'd have to do the thing, so it became a focus away from me. I could focus that we were doing this for her benefit, or for both the 
girls' benefit, so for me the introduction was not for any grand - I was going to have this child who was going to be right into music and want to be in an orchestra or somewhere across the world when she was older. That was never the intention. The intention was just to recognise that I wasn't well and I needed to get out of the house and we've chosen to do this because I could do it with her... Well. It got me well.

Connecting with community was also an initial reason for enrolling in a MELP for Sarah. She recalls moving into the community where

'I knew nobody and I thought what's the best way to meet people when you've got young kids and I saw the sign basically, but I always thought I want the kids to do music. I always thought after being at Uni, I want the kids to do music'.

Stella (2) recalls the classes as 'really, really good fun...It was a nice way to spend that one-on-one time, to calm down and spend that one-on-one time with each of them. So much so, that after I had the twins I got someone to come in and look after the twins so I still had that beautiful time with Ollie (aged 3)'. This aspect of having time prioritised for one-on-one engagement was another key reason for Stella's enrolment with Ollie.

Brenda's (grandparent) reasons for attending the MELP were multi-faceted. As noted above she sought to re-dress an absence of music-education in the childhoods of her own children. She also appreciated the opportunity to '...spend time with my grandchildren, and being stupid, and being allowed to do whatever you like and get away with it, I guess. We have lots of fun.... And to see them enjoying it, it gives everyone pleasure, music, I believe'. Brenda also spoke of the social benefits of attendance at the MELP for her grandchildren noting that '...they became friends with some of the children, and I became friends with the children's mothers, and they're still friends'.

As a component of a home education curriculum

Lenora, who is home educating both of her children was "looking for something that would incorporate play and music and socialisation...something that was going to involve a range of different skills that would be developed at the same time...friends of ours were doing the MELP program and recommended it, so we went along to a 'go and try' class and just fell in love with it'. 


\section{RQ3. What are their aspirations for their child's participation?}

Parents' aspirations for their child's participation overlapped with their reasons for enrolling their child in a MELP. Aspirations included a belief in the value-adding contributions of music to their child's developmental and learning outcomes, a wish to expand their child's social circle and play opportunities, and a desire to have their child exposed to music. This last was presented as both an aspiration to have their children enjoy music as they (the parents) had in childhood (see Sally), or to redress a perceived absence from their own childhoods (see Marion). Parents' aspirations were multi-faceted and complex with these three elements occurring across the interviews (see Sally).

Exposure to music, value-adding and expanding the social circle

Sally's prime aspiration was for her children 'to feel comfortable with music... to be exposed to music, and to feel the freedom that music provides...' as well as contributions to development and learning outcomes commenting:

I really loved the fact that I felt like they were learning in different aspects of their world because they had done music, whether it be maths or whatever, because they could do things to a beat or to a song, and that would help him learning it. I can remember being at school, and my French teacher saying prepositions to us, and I still remember them because they were in a song...it's that kind of learning that I really liked that had come from music'.

Given her own limited background in music Marion's primary reason for enrolling Amy in the MELP was so '...she could have a good understanding of music'. However, as they attended classes, Marion became aware of the social benefits, reporting that, as an only child, 'she enjoyed being with people, and she loved the music'.

\section{RQ4: What are the life and learning outcomes for their child from participation?}

Parents identified a range of life and learning outcomes from participation in the MELP including developed skills and knowledge in music, increased physical development, increased confidence and openness to learning, and increased social networks.

\section{Developed skills and knowledge in music}

'I think they're not scared of music. I think they enjoy music...they can pick it up as a...it's soothing, it's invigorating...they'll pick something up and just play it without having to learn it as such... 
(Sally). Lenora also comments on the 'Foundational things' that were learnt through the program commenting 'I know of parents whose children have just started music when they've gone to school, the school program, and they often don't stick at it because they haven't had this love, the play aspect, and the way that was really beautifully incorporated'.

For the children, much of the 'music stuff' that they acquired through the program (instruments, notation cards, reading charts) continue to be part of their musical play. Amy reports "I have a glockenspiel, a drum, tambourines and all those kind of things' with which she still plays and continues to draw on the repertoire learnt at the MELP. In stating her aspirations for continuing music engagement, Amy states 'I want to get my family to do music as well'.

An investment for the future

In discussing the enduring outcomes of participation in the MELP, Lenora states 'financially, I'd say to people, it's an investment, but it's a worthwhile investment and I think it's something you've got your whole life. It's a skill'. Her daughter, Sylvie, adds 'I think I have gradually grown to like music more... and I think it helped us learn to be helpful'. She continues to describe her current project playing 'at the local home school concert (we) go there, go play with friends of ours - old friends at the retirement villages that sort of thing and they enjoy it and I can pull out my old music and give them a little concert'. This ethos of 'giving back' is viewed by Lenora as 'a flow-on effect, investment, not just for now in their lives, but I think, forever'.

Increased physical development

'...there's some coordination stuff that was really good...particularly...the crossing the midline things that I remember we used to do...arm to opposite foot and that kind of stuff'. (Sally).

Increased confidence, openness to learning, and learning strategies

'...because they were exposed to it from an early age, they're a bit more open to learning new things. They don't get really scared of "It's a new thing. I can't do it...' (Sally). Carl, Sandy's oldest son remarks 'I guess I've just found where I have more confidence in expressing myself and enjoying myself...I can actually achieve something if I just break it down and start it all and get bigger as I progress'. 
Marion comments that 'I think she's definitely confident to do things in public which is pretty astounding some of things she does in front of an audience...she's always been pretty good at sharing stuff which for an only child l've though was a pretty good thing'.

Increased social awareness, self-regulation, and social networks

For parents and child participants alike, the development of increased social awareness, selfregulation, and social networks were viewed as enduring outcomes. As Marion commented '... being able to play with other children and learning to sit down when you're told for other people, and to learn respect for other people in that way, and other kids. When they've got to play, you've got to be quiet, that sort of discipline and just... a really good time'. These sentiments are echoed by Sally, who notes that, for child participants '...they feel like they're part of a bigger family' (Sally). Brenda comments 'I think they learn to socialise with other children, and with adults, and to listen, and a bit of patience...to sit still where a lot of children can't learn to sit still...they have to wait their turn...I think they have listening skills...and a few manners'.

Amy comments that one of the enduring outcomes for her has been the increased social networks, and 'The friendships, yeah, definitely the friendships'.

\section{Establishing patterns of learning and a learning tool}

Ellen speaks of the ways in which the MELP activity structure taught her two girls about the nature of learning and progression. She comments

'They learn that things didn't occur in isolation. You just didn't go to that class and then nothing happened until you go again next week. You actually had to do things during the course of the week and then go back to the class and move on. Not that it was homework as such, but it just wasn't in isolation.... You go to class and you do this work and you have to go home and you have to either practise that page of music, or read the book five times, or sing the song, or whatever it was, and that we would then do it over the course of the week and then come back to the next class and you would move on from that. I guess they learnt that from very young, that's what you do. When that came to school and getting a reader it has been no effort on my behalf whatsoever at any point to get my children to recognise that you've come home, you've got work to do and you do it for whenever it's due'. 
Parents Kara and Max also comment on the role of the MELP in establishing patterns of learning recalling 'Every week was a little task. So, it was setting the pattern for routines for preschool and school, responsibility on his part, organisation'. Their son Joe now busks in the town centre on week-ends, encouraging the audience to sing-along. The MELP leader is attributed with prompting Joe to busk. As Max states 'Well the MELP leader started it'. His wife continues:

'She got him to busk years ago, he was only about seven or six one frosty cold morning at the farmer's market... and then some[one] suggested about two years ago that he do it on a Saturday morning... and then the owner of the farmer's market rang and asked could he do it every second farmer's market because he was the only reliable person who would turn up and play'.

Joe continues, 'Busking's a great thing. I think the performances in front of other people (at the MELP) that really helped with the busking...if I hadn't done these group exercises I might not have even wanted to do busking...but at the MELP, I realised it's your music and how you play it is how you play it'. For Joe, the early group classes were crucial in his music development. 'I don't think I would've got into piano at all if it wasn't for that having a basic understanding first and then moving into it. I think if I'd gone straight to piano lessons like some other people might when they turn 10 or 11, I just wouldn't have got it, or enjoyed it or clicked with it, if I hadn't had that basic structure...'.

Lenora spoke at length of the ways in which she drew on music in her early home-schooling and subsequent work as a language teacher in schools, as a learning tool. 'I use songs a lot to get children to learn vocabulary and to enjoy what they are doing, enjoy the learning experience...'. The three continued with a lengthy description and demonstration of songs created in the home to 'remind Daddy (who) used to leave the house without his stuff (all three sing)...Laptop, palm pad, keys, pen, phone, keys, pen phone, keys, pen phone...'.

For Sarah, whose four boys attended the MELP, participation 'set the boys up really well. It taught them how to sit, how to concentrate, how to listen to another adult, how to have, okay, well, there's other people in the group - it's not just all about me and those sorts of skills as well as the music side of things...the music side of things was great for counting, great for calming them...those sort of things'. In elaborating on what her boys have learnt from the project, she continues 
'Hard work pays off. If you want to play an instrument you actually have to work at it, which is in life, if you want to succeed at something, you actually have to work at it... think by doing the hard work and practising, that's showed them that, yes, you do get success and I feel really good about myself...that's a cycle...the self-esteem and confidence is massive... hard work and practice pays off'.

\section{Discussion}

Findings indicate that the drivers for participation in MELPS for these parents include: musical learning and development for both parent and child (Abad \& Barrett, 2016); bonding between parent and child (Barrett, 2009; Custodero \& Johnson-Green, 2003); socialisation for both parent and child (Pitt \& Hargreaves 2017a, 2017b; Scott-Hall, 2005); acquisition of parenting strategies (Ilari, Moura \& Bourscheidt, 2011; Morris, 2013; Young, Street \& Davies, 2007); promoting parental well-being (Fancourt \& Perkins, 2017; Gudmundsdottir \& Gudmundsdottir, 2010; Kawase \& Ogawa 2018); contributing to a home education curriculum; and, facilitating engagement with a wider community. These findings are interrelated, providing a rich retrospective view of enduring impacts and cultural continuity as parents' reflected on their own childhood experience of music and their musical aspirations for their children. For some, a perceived lack of music education in their own childhoods prompted them to ensure that their children did not experience a similar lack. These participants hold a belief in the value-adding contributions of music to their child's developmental and learning outcomes, a wish to expand their child's social circle and play opportunities, and a desire to have their child exposed to music, regardless of their own prior experience.

A number of implications for practice arise from these findings. Understanding of the multifaceted nature of parents' reasons for attending MELPs offer suggestions for the structuring of MELPs classes as learning and socialisation experiences for the parent as well as the child. Consideration of the potential for MELPs to contribute to parental health and well-being as outlined in the findings and other literature (Fancourt \& Perkins, 2017; Gudmundsdottir \& Gudmundsdottir, 2010; Kawase \& Ogawa 2018) holds implications for local and national social health services in seeking to increase access to such programmes for parents, to promote social engagement, participation, and health and wellbeing (cf Fancourt \& Finn, 2019).

Findings suggest that children are likely to arrive at formal schooling with a rich repertoire of music, a capacity to engage in embodied musical experience, and a set of expectations 
concerning their participation in music. Such knowledge holds implications for the ways in which music learning might be structured within the EC classroom.

The dataset arises from a particular group of parents who demonstrated a long-term commitment to MELP engagement. Although this may represent a certain bias, the analysis and reporting focus has been to understand why this group invested in MELP. Further research might investigate perspectives of participants who begin and drop out of such programmes, or those who decline or are unable to enrol their children. Whilst this study didn't interrogate any independent aspects of quality, other than through participant memory, it might be speculated that a program of some 20 years standing in a community with a pattern of generational family involvement must be of sufficient quality to ensure continuing long-term participation. Nevertheless, further investigation of what constitutes quality provision in the MELP industry is warranted.

\section{Funding}

The author(s) disclosed receipt of the following financial support for the research, authorship, and/or publication of this article: This research was funded by the Australian Research Council Discovery Grant program: Barrett, M.S. \& Welch, G.F. (2013 - 2016). Being and becoming musical: towards a cultural ecological model of early musical development. ARC Discovery Grant Project ID: DP130102488. This research was completed whilst Author 1 was located at The University of Queensland.

\section{References}

Abad, V. \& Barrett. (2016). Families and Music Early Learning Programs: Boppin' Babies. In S.L. Jacobsen \& G. Thompson (Eds.), Music therapy with families: Therapeutic approaches and theoretical perspectives (pps. 135-151). London: Jessica Kingsley Publishers.

Adachi, M., \& Trehub, S. E. (2012). Musical lives of infants. In G. McPherson, \& G. Welch (Eds.), The Oxford Handbook of Music Education (pp. 229-247). New York, NY: Oxford University Press. Anvari, S.H.J., Trainor, L.J. Woodside, J., \& Levy, B.A. (2002). Relations among musical skills, phonological processing and early reading ability in preschool children. Journal of Experimental Child Psychology, 83 (2), $111-130$.

Barrett, M. S. (2006). Inventing songs, inventing worlds: The "genesis" of creative thought and activity in young children's lives. International Journal of Early Years Education, 14(3), 201220. 
Barrett, M. S. (2003). Meme engineers: Children as producers of musical culture. International Journal of Early Years Education, 11(3), 195-212.

Barrett, M. S. (2009). Sounding lives in and through music: A narrative inquiry of the 'everyday' musical engagement of a young child. Journal of Early Childhood Research, 7 (2), 115-134.

Barrett, M. S. (2011). Musical narratives: A study of a young child's identity work in and through music-making. Psychology of Music, 39 (4), 403-423.

Barrett, M. S. (2012). Music learning and education in early childhood: An overview. In G. E. McPherson \& G. F. Author (Eds.), Oxford handbook of music education (pp. 227-228). Oxford, UK: Oxford University Press.

Barrett, M.S. (2016a). Attending to "culture in the small": a narrative analysis of the role of play, thought, and music in young children's world-making. Research Studies in Music Education, 38 (1), 41-54.

Barrett, M.S. (2016b). Laying the foundations for narrative identities in and through music. In R. MacDonald, D. Hargreaves, \& D. Miell (Eds), Handbook of musical identities (pp. 63-78).Oxford: Oxford University Press.

Barrett, M., Zhukov, K., \& Brown, J.E., \& Welch, G.F. (2018). Evaluating the impact of a generalist teacher-led music program on early childhood school children's singing skills and attitudes to music. Psychology of Music, Online 16 August 2018. DOI: 10.1177/0305735618790355

Blackburn, C. (2018). Promoting children's wellbeing, right to make choices and engage in playful activities in restricted environments through music and singing. Birmingham: Birmingham City University. DOI: 10.13140/RG.2.2.33078.40001

Brown, E. D., \& Sax, K. L. (2013). Arts enrichment and preschool emotions for low-income children at risk. Early Childhood Research Quarterly, 28, 337-346.

http://dx.doi.org/10.1016/j.ecresq.2012.08.002

Costa-Giomi, E., \& Sun, X. (2016). Infants' home soundscapes: A day in the life of a family. In J. Bugos (Ed.), Contemporary research in music learning across the lifespan. London: Taylor \& Francis.

Custodero, L., Cali, C., \& Diaz-Donoso, A. (2016). Music as transitional object and practice: Children's spontaneous musical behaviours in the subway. Research Studies in Music Education, $38(1), 55-74$.

Custodero, L. A., \& Johnson Green, E. A. (2003). Passing the cultural torch: Musical experience and musical parenting of infants. Journal of Research in Music Education, 51(2), 102-114. 
Fancourt, D., \& Finn, S. (2019). What is the evidence on the role of the arts in improving health and well-being? A scoping review. World Health Organisation Europe.

Fancourt, D., \& Perkins, R. (2017). Does attending community music interventions lead to changes in wider musical behaviours? The effect of mother-infant singing classes on musical behaviours amongst mothers with symptoms of postnatal depression. Psychology of Music, 47(1), 132-143. https://doi.org/10.1177/0305735617742197

Finnegan, R. (1989). The Hidden Musicians: Music-making in an English Town. Cambridge: CUP. $2^{\text {nd }}$ Edition 2007, Middletown, CT, USA: Wesleyan University Press.

Gromko, J.E. (2005). The effect of music instruction on phonemic awareness in beginning readers. Journal of Research in Music Education, 53 (3), 199 - 209.

Gromko, J.E., \& Poorman, A.S. (1998). The effect of music training on pre-schoolers spatialtemporal task performance. Journal of Research in Music Education, 46 (2), $173-181$.

Gudmundsdottir, H.R. (2018). Revisiting singing proficiency in three-year-olds. Psychology of Music. https://doi.org/10.1177/0305735618798031

Gudmundsdottir, H.R., \& Gudmundsdottir, D.G. (2010). Parent-infant music courses in Iceland: perceived benefits and mental well-being of mothers. Music Education Research, 12(3), 299 309.

Hallam, S. (2015). The power of music: A research synthesis of the impact of actively making music on the intellectual, social and personal development of children and young people. Department of Culture, Communication and Media, UCL Institute of Education, University College, London: Music Education Council and International Music Education Research Centre (iMERC).

Hallam, S. (2016). The impact of actively making music on the intellectual, social and personal development of children and young people: A summary. Voices: A World Forum for Music Therapy, 16(2), 1-13.

Ilari, B. (2016). Music in the early years: Pathways into the social world. Research Studies in Music Education, 38(1), 23-39.

Ilari, B., Moura, A., \& Bourschiedt, L. (2011). Between interactions and commodities: Musical parenting of infants and toddlers in Brazil. Music Education Research, 13 (1), 51 - 67.

Kawase, S., \& Ogawa, J. (2018). Group music lessons for children aged 1-3 improve accompanying parents' moods. Psychology of Music, First published online October 19, 2018.

https://doi.org/10.1177/0305735618803791 
Kirschner, S., \& Tomasello, M. (2010). Joint music making promotes prosocial behavior in 4-year-old children. Evolution and Human Behavior, 31, 354-364. http://dx.doi.org/10.1016/i.evolhumbehav.2010.04.004

Kraus, N., Slater, J., Thompson, E.C., Hornickel, J., Strait, S., Nicol, T., \& White-Schwoch, T. (2014). Music Enrichment Programs Improve the Neural Encoding of Speech in At-Risk Children. The Journal of Neuroscience, 34(36), 11913-11918. DOI:10.1523/JNEUROSCI.1881-14.2014

Maróti, E., Barabás, E., Deszpot, Farnadi, T., Nemes, L.M., Szirányi, B., \& Honbolygó. (2018). Does moving to music make you smarter? The relation of sensorimotor entrainment to cognitive, linguistic, musical and social skills. Psychology of Music, 47(5), 663-679. https://doi.org/10.1177/0305735618778765

Morris, C. (2013). Sound Foundations: early years music project. Music Matters Magazine, 19-21. Nome, D. (2018). Social life among toddlers in kindergarten as communicative musicality. Psychology of Music. https://doi.org/10.1177/0305735618816159

Polkinghorne, D. (1995). Narrative configuration in qualitative analysis. International Journal of Qualtiative Studies in Education, 8(1), 5 - 23.

Pitt, J. \& Hargreaves, D.J. (2017a) Attitudes toward and perceptions of the rationale for parent-child group music making with young children. Music Education Research, 19(3), $292-308$.

Pitt, J. \& Hargreaves, D.J. (2017b). Exploring the rationale for group music activities for parents and young children: Parents' and practitioners' perspective.

Phillips, R. D., Gorton, R. L., Pinciotti, P., \& Sachdev, A. (2010). Promising findings on preschoolers' emergent literacy and school readiness in arts-integrated early childhood settings. Early Childhood Education Journal, 38 (2), 111-122.

Portowitz, A., Lichtenstein, O., Egorova, L., \& Brand, E. (2009). Underlying mechanisms linking music education and cognitive modifiability. Research Studies in Music Education, 31, 107-129.

Putkinen, V., Tervaniemi, M., \& Huotilainnen, M. (2013). Informal musical activities are linked to auditory discrimination and attention in 2-3 year old children: an event-related potential study. European Journal of Neuroscience, 37 (4), 654-661.

Rogoff, B. (2003). The cultural nature of human development. New York: Oxford University Press. Scott-Hall, E. (2008). Mothers Too: The effects of a music project on participants in an inner city area of social and financial deprivation. Paper presented to the $13^{\text {th }}$ Early Childhood Music Education (ECME) Commission Seminar, Frascati, Italy, July 14 - 19. 
Sole, M. (2017). Crib song: Insights into functions of toddlers' private spontaneous singing. Psychology of Music, 45(2), 172-192.

Williams, K.E., Barrett, M.S., Welch, G.F., Abad, V., \& Broughton, M. (2015). Associations between early shared music activities in the home and later child outcomes: Findings from the Longitudinal Study of Australian Children. Early Childhood Research Quarterly, 31, 113-124.

Williams, K.E., \& Berthelsen, D. (2019). Implementation of a rhythm and movement intervention to support self-regulation skills of preschool-aged children in disadvantaged communities. Psychology of Music, 47(6), 800-820.

Winsler, A., Ducenne, L., \& Koury, A. (2011). Singing one's way to self-regulation: The role of early music and movement curricula and private speech. Early Education and Development, 22, 274304.

Young, S., Street, A., \& Davies, E. (2007). The music one-to-one project: Developing approaches with parents and under-two-year-olds. European Early Childhood Education Research Journal, 15, 253-267. 